\title{
Career Maturity Among High School Students in Medan
}

\author{
Rika Eliana1, Sri Supriyantini², Josetta M.R.Tuapattinaja ${ }^{3}$ \\ Psychology Faculty University of Sumatera Utara \\ Medan, Indonesia \\ rika.eliana@usu.ac.id ${ }^{1}$,sri.supriyantini@usu.ac.id², josetta@usu.ac.id ${ }^{3}$,
}

\begin{abstract}
This purpose of this research was to know about career maturity of high school students. Career maturity needs to be examined considering many students not ready to choose a career direction when later graduated high school. As for this research involve 206 students from several schools in Medan City. We used the Career Maturity Inventory form C by Crites \& Savickas [8] who were adapted into Indonesian language. CMI Form C provides a total score for career choice readiness, and consist of four dimension as follows concern, curiosity, confidence, and consultation. The results showed Career maturity of high school students in Medan in middle category. The dimensions of Concern and Consultation are higher than the dimensions of Curiousity and Confidence. This indicates that high school students are still not looking for more information about their career, and also not confidence about their ability. Because of that increased awareness of careers is indispensable to increase the maturity of high school student career
\end{abstract}

Keywords: Career maturity, concern, curiosity, confidence, consultation

\section{INTRODUCTION}

It can't be denied that students that are still in high school have hope to continue their education to a higher level or planning a career in accordance with the field they were majoring. As proposed by the Monks (1998) that after students graduate from high school, several students will continue their education to college, but there are also several who might want to work. This is inline with their development tasks as a adolescence according to Havighurst (in Santrock, 2012). In fact, in choosing a field of study is not as easy as imagined. The results showed that not all children and adolescence have the opportunity to be able to analyze the direction of their interest (Brown, D., 2002). Research conducted by Gottfredson (in Brown, D., 2002) shows that social pressure, discrimination, culture can affect a wide variety of career options for adolescence. The phenomenon of selecting the fields of study for high school students today are still mostly done by the choice of other friends, desire or direction of parents, and may be limited to the favourite field of study. Based on the observation of high school students who took the talent tests in Psychology Community Service Center (P3M) Faculty of Psychology, University of North Sumatra, shows that most students are still confused in determining the direction of major for further education. The students are still not ready to make choices and career decisions that they will practice in the future, Inaccuracy in choosing a field of study may have an impact on the students where they find it difficult in studying, students become less motivated to carry out the study, so that the period of study become longer. In the long-run, students can fail in their career because it does not correspond to their potential. Readiness of students in making career choices and decisions that will be 
practiced in the future, in accordance with the demands of the age and stage of development is called the career maturity. Super (in Winkel, W.S., 2010). argued that career maturity is an individual's awareness of their success in completing specific career developtment tasks for certain developmental stage. In line with the opinion of the Super, Crites (in Salami, S.O., 2008). States that career maturity is the extent to which individuals can master their career development tasks including the knowledge component and attitudes that match their career development. Career maturity is important so that students were able to make decisions and realistic career decisions and will soon be able to perform optimally when entering the workforce.

Super (in Brown, D., 2002) states that the career development in adolescence are at the stage of Exploration, which took place at the age of 14-24 years. At this stage, adolescence learn about them self and their career in the future. Adolescence also get information about them self and suitable career choices. While high school students who are in the age range of 16-18 years by Super (in Brown, D., 2002) is at sub Crystallization stage, in which at this stage adolescence tried to explore them self to find out about the career choices appropriate for them. Adolescence can make a decision on career choices that exist by considering the interests, values and abilities that exist in them self. Super (in Salami, S.O., 2008) classifies the factors that affect career maturity in several groups, i.e: a). Biosocial factors, career maturity consists of the factors in accordance with the choices, information and specific plans, the acceptance of responsibility for the selection and that plans. The options are related to age and intelligence; b). Environmental factors, in which career maturity correlates with the parents occupation, school curriculum, cultural stimulation, and family cohesiveness. c). Factors vocational, career maturity correlates with career aspirations and the degree of correspondence between aspirations and expectations; d). Personality characteristics which include selfconcept, special talents, values / norms and purpose of life; e). Individual achievement, where individual achievement is associated with career maturity, such as grade level, participation in school and activities outside of the school.

Career maturity consists of several dimensions. According to Savickas (2001) there are four dimensions in career maturity, where the fourth dimension shows the ability of individuals to adapt to the demands of career and strategies used, which includes a specific attitude, confidence, and competence that shape the concrete behavior used in adapting. According to Savickas (2011) attitude and belief is a disposition that reflects how they see things. These four dimensions are: a). Concern is the care for the future or the extent to which the individual-oriented and involved in the decisionmaking process of individuals career. Individuals concern toward their career means individuals have orientation towards the future which is important in preparing for the future. This shows the awareness of people to tasks of career development and career transition that must be faced and the choices to be made in the near term and long term. Individuals should make plans for themselves, anticipating, recognizing, engaging, and oriented towards future career. Lack of attention to the career is ignorance of the career and it reflects the absence of plans, and pessimism about the future. b). Curiosity, is the feeling of curiosity to try and find opportunities within the social environment. Curiosity refers to the initiative in studying the workforce that leads to information seeking behavior, including their openness to new experiences, explore yourself, and reflect on the compatibility between the self and the work force. The lack of curiosity can be seen as a lack of clarity over the work force and a self-concept that is inaccurate. c). Self Confidence, the confidence to engage in future career planning and implementing their plans. The confidence showed anticipation of success in solving complex problems related decision making career and job options. Confidence shows the extent to which an individual has confidence in her or his ability to make wise career decisions and choosing a realistic career or job. This includes their confidence to be able to successfully execute the behavior required to overcome the challenges and overcome obstacles in making and implementing decisions. Individuals need the 
confidence to act on their interests and aspirations. The lack of confidence showed the existence of barriers in career development. d). Consultation shows the extent to which an individual is looking for assistance in career decision-making by requesting information or advice from others. This reflects their sense of responsibility to build a career through firm action, assertive, and carefully rather than relying on chance or luck. Individuals choose with discipline, awareness, goal-oriented, and organized approach in implementing the developmental tasks of their career.

The profile of the four dimensions provides an overview of individual attitudes toward career decision-making and readiness to make the decision of occupation.

Based on the above ideas, researchers are trying to find the description of career maturity of high school students in Medan.

\section{METHOD}

\section{A. Participants}

This research used participants of 206 students of class XI from three high schools in Medan that were selected by using random cluster sampling technique.

\section{B. Instrument}

Career maturity is measured by using the Career Maturity Inventory Form $\mathrm{C}$ created by Crites \& Savickas $[8,9]$ which has been adapted into Indonesian. Career Maturity Inventory Form C consists of four dimensions, that are Concern, Confidence, Curiosity, and Control / Consultation. This inventory consists of 24 items designed by using two choices answers, and presented in the form of a favorable statement (supporting) and unfavorable (no support). Coefficient alphas for the the resulting four 6 -item scales were concerned $1 / 4$ .62 , control $1 / 4.69$, curiosity $1 / 4.74$, and confidence $1 / 4.78$. Score rates to the favourable statement, are: choice answers have score of $1=$ Agree, and Disagree $=$ has a score of 0 . While the score rates of unfavorable statements are: the choice of answers Agree $=$ has a score of 0 , and Disagree $=$ has a score of 1 . The higher the score obtained means higher career maturity of the students. Conversely, the lower scores obtained means lower students' career maturity.

\section{Data Analysis Method}

The data in this study analyzed quantitatively to look for the mean and standard deviation with the help of SPSS for windows 16.

\section{RESULTS}

Based on research conducted data analysis, the following are results of research.

Table 1. Overview of career maturity of students

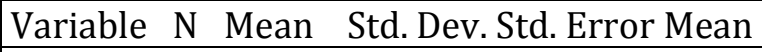
Career

$\begin{array}{llll}\text { Maturity } 206 & 13.21 & 3.058 & .213\end{array}$

From Table 1 above, can be seen that the career maturity of students is in middle category (mean: 13:21, SD: 3058)

Table 2. Overview of career maturity of students per dimension

\begin{tabular}{|lccccc|}
\hline Dimension & N & Min & Max & Std.Dev & Mean \\
\hline Concern & 206 & 0 & 6 & 1.195 & 4.30 \\
& & & & & \\
\hline Curiosity & 206 & 0 & 6 & 1.559 & 2.62 \\
& & & & & \\
\hline Confidence & 206 & 0 & 6 & 1.528 & 2.05 \\
\hline Consultation & 206 & 0 & 6 & 1.073 & 4.24 \\
\hline
\end{tabular}

From table 2 above can be seen that the dimensions of Concern (mean: 4.30) and Consultation (mean: 4:24) higher than Curiosity dimensions (2.62) and Confidence (2:05).

The results showed that in general career maturity of students in middle category. When viewed per dimension, it is known that the 
dimensions of Concern and Consultation are higher than the dimensions of Curiousity and Confidence. This suggests that high school students have shown concern for career and their future. They are aware of the tasks of career development and career transition that must be faced and the choices to be made in the near term and long term. By their age that are still adolescence, they need consultation with the adults who have more experienced in life. They seek to consult and seek assistance in career decision-making by requesting information or advice from others, as a reflection of their sense of responsibility for them to build a career. On the other hand Confidence and Curiosity of students are still not strong. This means that students do not demonstrate initiative to learn about work force through the search of information about the work force. Besides, students are still lack of strong belief in themselves on their ability to make wise career decisions and choosing a realistic career or job. They are not sure to be able to succeed in overcoming the challenges and overcome obstacles in making and implementing decisiom. This is understandable, considering the students were still in class XI of high school. Savickas (2011) states that one of the things that is hard to do in adolescence is to make a decision on some of the career options available. Furthermore, according to Super (in Savickas, 2011) the individual is said to be ripe to make a career decision if the knowledge he/she has to make a career decision is supported by adequate information about the job done by exploration. Based on the student's profile,their attitude towards decision-making in their career and their readiness to make a career choice can be known.

In conclusion, this study show that career maturity of high school students in Medan in middle category. The dimensions of Concern and Consultation are higher than the dimensions of Curiosity and Confidence.

For further research is recommended to examine the factors that affect career maturity in high school students, e.g. grade level, participation in school and activities outside of the school, parents occupation, school curriculum, cultural stimulation, and family cohesiveness, special talents, values / norms and purpose of life.

\section{REFERENCES}

Brown, D.(2002). Career choice and development. (Fourth edition). San Francisco: Jossey-Bass.

Osipow, S.H. \& Fitzgerald, L.F. (1996). Theories of career development. (4th ed.). Boston : Allyn \& Bacon.

Monks, F.J., Knoers, A.M.P., \& Haditono, S.R. (1998). Psikologi perkembangan: Pengantar dalam berbagai bagiannya. Yogyakarta: Gadjah Mada University Press.

Salami, S.O. (2008). Gender, identity status and career maturity of adolescents in Southwest Nigeria. Journal of Science, 16(1): 5-49.

Santrock, J.W. (2012). Life span development. 13 th ed.University of Texas. Dallas : Mc.Graw Hill

Savickas, M, L. 2001. A Developmental perspective on vocational behavior: Career patterns, salience and themes. Netherlands: Kluwer Academic Publishers. Journal for Educational and Vocational Guidance.

Savickas, M.L. \& Porfeli, E.J. (2011). Revision of the Career Maturity Inventory. The Adaptability Form. Journal of career Assessment. 19 (4) 355-374.

Savickas, M. L. (2005). The theory and practice of career construction. In S. D. Brown \& R. W. Lent (Eds.), Career development and counseling: Putting theory and research to work . 42-70. Hoboken, NJ: John Wiley \& Sons.

Winkel, W.S. (2010). Bimbingan dan konseling di institusi pendidikan. Rev. ed. Yogyakarta: Media Abadi. 